\title{
The influence of principal leadership and compensation on teacher's performance at state junior high school
}

\author{
Renawati Renawati ${ }^{1}$,Yasir Arafat ${ }^{2}$, Mulyadi Mulyadi $^{2}$ \\ ${ }^{1}$ Sekolah Menengah Pertama Negeri 2 Babat Supat, Indonesia \\ ${ }^{2}$ Universitas PGRI Palembang, Indonesia
}

\begin{tabular}{l}
\hline Article Info \\
\hline Article history: \\
Received Jul $14^{\text {th }}, 2021$ \\
Revised Aug $17^{\text {th }}, 2021$ \\
Accepted Aug $30^{\text {th }}, 2021$ \\
\hline
\end{tabular}

\section{Keyword:}

Compensation

Leadership

Teachers' performance

\begin{abstract}
This study aimed to determine: (1) the influence of principal leadership on teachers' performance; (2) the influenceof compensation on teachers' performance; and (3) the influenceof principal leadership and compensation simultaneously on teachers' performance. The data in this study were collected through distributing questionnaires to respondents and were analyzedby using multiple regression analysis through the $\mathrm{t}$ test, $\mathrm{F}$ test, and determination coefficient test. The population in this study were all teachers of SMP NegeriatBabatSupat sub-district, MusiBanyuasin Regency, totaling 134 people. The sampling technique used was probability sampling by using the Slovin formula to obtain 100 teachers as the research sample. The results of the study found that: (1) there was a significant influence between principal leadership on teachers' performance; (2) there was a significant influence between compensation on teachers' performance; (3) there was a significant influence between principal leadership and compensation on teachers performance.
\end{abstract}

(C) 2021 The Authors. Published by IICET.

This is an open access article under the CC BY-NC-SA license (https://creativecommons.org/licenses/by-nc-sa/4.0

\section{Corresponding Author:}

Renawati, R.,

Sekolah Menengah Pertama Negeri 2 Babat Supat, Indonesia

Email: renawati765@gmail.com

\section{Introduction}

The demands of modern times today in order to realize the basis, function and objectives of the Law on the National Education System of the Republic of Indonesia, the authority to provide formal education in society is exercised in schools. School as an organization is said to be successful if it can encourage, organize, and direct all elements in it to achieve organizational goals, namely the goals of school and national education. The elements referred to are none other than human resources consisting of the principal, teachers, staff, students, and parents of students.

The success of an organization as a whole and various groups in a particular organization, is highly dependent on the authority of the leadership contained in the organization concerned, a leader must be able to create a harmonious working relationship, among employees, and between superiors and subordinates. In this case, the principal as someone who is assigned to the school, is responsible for the achievement of school goals. Principals are expected to be leaders and innovators in schools. Therefore, the leadership quality of the principal is important for the success of the school. 
A simple definition of leadership [1] is a person's ability to influence others. This implies that leadership is a person's ability to influence or direct others so that others submit to or follow all the wishes of a leader.

[2] Principals with high professionalism will certainly have a major influence on the progress of an educational institution. [3] Every school principal must have a spirit and attitude that can provide an example and role model for his subordinates, including the principal who leads the organization in the school environment, every school principal must be able to become a motivator and motivator for his subordinates, in order to create memorable learning situations and conditions . [4] Principals are highly required to be able to give influence to teachers to carry out their duties professionally.

Principal leadership is a determining factor in the continuity and development of educational organizations. By unifying school components consisting of principals, teachers, workers, and students is one way to achieve more optimum achievement in the world of education. Teachers are an important component and resource that must be fostered and developed continuously [2]. To empower teachers with regard to achievement requires a large investment and takes a long time. Most of the people do not deny the importance of quality teacher achievement, because the key to school success depends on these sources.

[5] Teacher achievement is something that is produced by a teacher in carrying out tasks based on their abilities, skills, experience, abilities and according to their abilities. A teacher's achievement is said to be good if the teacher has carried out elements consisting of high loyalty and commitment to teaching tasks, mastering and developing learning materials, discipline in teaching and other tasks. Creativity in the implementation of teaching, cooperation with all school members, leadership that is an example to students, good personality, honesty and objectivity in guiding students and responsibility for their duties. Discussing the problem of the quality of teacher achievement cannot be separated from the achievement of learning outcomes. This is because teacher achievement determines the success of a memorable and capable learning process so that educational goals can be achieved and realized from good learning outcomes which can ultimately produce quality graduates.

[6] the success of a teacher in carrying out tasks to achieve a particular goal is determined by the performance of teachers. [7], performance is, "the work achieved by a worker or group of workers in an organization is in accordance with the authorities and responsibilities in the organization concerned legally, does not violate the law and is in accordance with morals and ethics".

Apart from the leadership of the principal, another factor that has an influence on teacher performance is compensation. Compensation is intended as a reward for the sacrifice of time, energy, and thoughts that the teacher has given in educating their students. [8] Compensation is something that employees receive as a substitute for their service contribution to the company.

This research was conducted at State Junior High Schools in BabatSupat District, MusiBanyuasin Regency. Based on preliminary observations made by researchers on May 20, 2020, it is known that the performance of teachers at SMP NegeriBabatSupat still needs to be improved, this can be seen from 1) the lack of ability of some teachers in designing lesson plans that can attract students' interest. This is necessary to shape the learning process, and create a learning process that is both educational and creative and interactive; Some teachers do not prepare learning media so that there is interaction between teachers and students in the teaching and learning process; 3) Some teachers are still lacking in mastery of information and communication technology, especially for some senior teachers, as well as a lack of teacher participation in professional development activities that should be followed in schools. So that the teacher's ability to determine how to deliver material and manage teaching and learning interactions will be greatly reduced.

The low ability of teachers which leads to low teacher performance at SMP NegeriBabatSupat District can occur due to, among others, the lack of assertiveness and authority of the principal as a leader in providing direction, guidance and motivation to teachers to be able to improve performance in the learning process in the classroom. In addition, the compensation received by SMP Negeri teachers in BabatSupat District, especially teachers with honorary status, is still low. Because they have honorary status, the compensation they receive is indeed very different from that of civil servants. The large amount of compensation received requires teachers to further improve their performance in schools.

Thus, the results of preliminary observations made by researchers indicate that the principal's leadership and compensation received by SMP Negeri teachers in BabatSupat District were thought to have a relationship with their performance. Therefore, researchers were interested in carrying out further research on the effect of principal leadership and compensation on teacher performance in public junior high schools in BabatSupat district, MusiBanyuasin district. 


\section{Method}

This research was a correlational research, which was a research conducted by researcher to determine the level of the relationship between two or more variables, without making changes, additions or manipulations to existing data [9]. In thisresearch, principal leadership and compensation as independent variables were tested for their effect on teachers' performance as the dependent variable.

The population in this research were all SMP Negeri teachers ofBabatSupat District, totaling 134 people with the following population characteristics.

Table 1. Research Population

\begin{tabular}{lcc}
\hline No & School Name & Total \\
1 & SMP Negeri 1 BabatSupat & 26 \\
2 & SMP Negeri 2 BabatSupat & 30 \\
3 & SMP Negeri 3 BabatSupat & 14 \\
4 & SMP Negeri 4 BabatSupat & 9 \\
5 & SMP Negeri 5 BabatSupat & 16 \\
6 & SMP Negeri 6 BabatSupat & 10 \\
7 & SMP Negeri 7 BabatSupat & 13 \\
8 & SMP Negeri 8 BabatSupat & 16 \\
& Jumlah & $\mathbf{1 3 4}$ \\
\hline
\end{tabular}

The sampling technique used in this research was probability sampling technique. Sugiyono (2012: 164) explained that probability sampling is a sampling technique that provides equal opportunities for each element (member) of the population to be selected as a sample member. The number of samples was determined by means of calculation by using the Slovin formula and obtained a sample size of 100 respondents.

Data collection techniques in this research were carried out through observation, documentation, and questionnaires.Data that had been provided by respondents in questionnaires that had been distributed, processed and used to provide an overview or explanation of the respondents' responses to each questionnaire item given through descriptive statistical tests and inferential statistics. The inferential statistics used were simple regression analysis and multiple regression analysis. Simple regression analysis techniques used in this research were partial test ( $\mathrm{t}$ test) and simultan test $(\mathrm{F}$ test). The classical assumption tests carried out were normality, heteroscedasticity,multicollinearity, homogeneity, and linearity tests.

\section{Results and Discussions}

\section{Normality Test}

Kolmogorov Smirnov-z value for the teacher performance variable was .083 , the leadership variable was 0.078 , and the compensation variable was .085. Asymp value of teachers' performance variable was .083 , the leadership variable was 0.136 , and the compensation variable was .069; The sig values were greater than 0.05 , it can be stated that the researchvariables used in this researchhad a normal distribution.

\section{Heteroscedasticity Test}

To detect heteroscedasticity in this study and to look at the presence or absence of a certain pattern on the scatterplot graph between SRESID and ZPRED, where the $\mathrm{Y}$ axis is the predicted $\mathrm{Y}$ and the $\mathrm{x}$-axis is the studentized residual (Y-predicted $\mathrm{Y}$ ). The results of the heteroscedasticity test showed that the distribution of data were around the zero point on the $\mathrm{Y}$-axis, and there was no visible pattern or trend line in the data distribution. This meant that there was no heteroscedasticity.

\section{Multicollinearity Test}

The results of the collinearity statistical test showed that the VIF value of the teachers' performance, leadership and the compensation variable were less than 10 (VIF < 10).Thus, the data tested had no multicollinearity symptoms.

\section{Homogeneity Test Results}

The results of Levene's test of homogeneity of variances showed that the significance value was $0.437 \geq 0.05$. Thus, the data was declared homogeneous. 


\section{Linearity Test}

The results of the linearity test through the means options test for linearity obtained a significant value of deviation from linearity of the principal leadership variable was 0.085 more than 0.05 and a significant value of deviation for linearity was less than 0.05 , meaning that there was a significant linear relationship between principal leadership and teachers'performancevariables. The significant value of deviation from linearity for the compensation variable was 0.195 more than 0.05 and the significant value for deviation for linearity was less than 0.05 , meaning that there was a significant linear relationship between the compensation and teachers' performancevariables.

\section{Hypothesis Testing Results}

The basis for the decision making for the $t$ test was to compare the calculated statistical value with the statistical table. If the $\mathrm{t}$-count statistic $\leq$ the $\mathrm{t}$-table statistic, then Ho is accepted and vice versa if the $\mathrm{t}$-count statistic $>$ the t-table statistic, then Ho is rejected.

1. The Influence of Principal Leadership Variables on Teachers' Performance of State Junior High Schools of Babat Supat District

Ha: $p>0$

Ho: $p=0$

H0: there was no positive and significant influence between principal leadership on teachers' performance.

Ha: there was a positive and significant influence between principal leadership on teachers' performance

It is known that $\mathrm{t}$-count $=9,701$ and $\mathrm{t}$-table $=1.98447$, then $\mathrm{t}$-count $>\mathrm{t}$-table. It meantHo was rejected and $\mathrm{Ha}$ was accepted, meaning that there was a positive and significant influence between the principal leadership on teachers' performance.

Table $2<$ Results of Partially Linear Regression Analysis of Variable X1 to Y >

\begin{tabular}{lcc}
\hline Model & $\mathrm{t}$ & Sig. \\
1 (Constant) & 3.829 & .000 \\
Principal leadership & 9.701 & .000 \\
\hline
\end{tabular}

The results of this research indicate that Hypothesis H01 was rejected and Hypothesis Ha1 was accepted or in other words, the variable of school principal leadership partially had an influence on the performance of SMP Negeri teachers of BabatSupat District. That was, if the leadership carried out by the principal was measured based on three-level indicators of academic supervision, namely: planning an academic supervision program; carry out academic supervision; and following up on the results of supervision; increased, the performance of SMP Negeri teachers ofBabatSupat District would also increase and vice versa if the quality of the principalleadership decreased the teacher's performance would also decreased. The results of descriptive analysis of the results of filling out questionnaires from research respondents indicated that the indicators of following up on the results of the leadership of the head of SMP NegeriofBabatSupat District get high responses based on the perceptions of SMP Negeri teachers ofBabatSupat District.

Through his leadership, the principal has the ability to influence teachers to cooperate in order to take actions and deeds in achieving common goals. Principal leadership is a form of individual behavior in interaction with the social system to achieve the goals of school institutions. Achieving the goals of the school organization is very dependent on the leadership used by the principal. Leadership behavior that is meant in general is a number of specific actions, in which the principal is involved in ways of directing and coordinating teachers and staff. Participation in these actions can take the form of a structured working relationship in dealing with and criticizing teachers and staff, and showing consideration for the welfare and feelings of teachers and their staff (Permadi\&Arifin, 2007: 38).

This result is also in line with the results of the researcher's observations, where the leadership of the principal at SMP NegeriBabatSupat sub-district was very good. The principal showed exemplary and dignity as a leader who provided many improvements that occur for the performance of his teacher. Teachers were becoming more disciplined and more actived in carrying out learning tasks under the guidance and supervision of the principal. For weaknesses, among them the principal was often not getting the latest information that was actually needed for the teachers he led. This was understandable 
because the condition of the area was quite difficult to reach information quickly, signal constraints, and others.

The results of this study also support the opinion of [10] which stated that the principal was one of the components of education that is influential in improving teacher performance. The principal as part of the school system was in a strategic position to direct and support teachers in student learning.

The results of this study support the results of the research of [11] which through their research stated that an increase in principal leadership would be followed by an increase of teachers' performance. Professional principals would supervise the performance of teachers and students in their schools, provide positive feedback for improvement and development of systems and learning methods, encourage the use of time and facilities for effective and creative learning.

The results of this study are also in line with the results of research conducted by [12] which stated that the factors that affect teacher professionalism and performance seen from the perspective of environmental input include factors of democratic school principal leadership, work climate in conducive school. Principal leadership is required to be able to provide continuous changes for improving teacher performance. Thus, the leadership of the principal plays a role in improving teacher performance in accordance with expectations. The results of this study also support the results of research conducted by [13] who found that there was an effect of principal leadership on teachers' performance.

2. The Effect of Compensation on the Performance of State Junior High School Teachers in Babat Supat District

$\mathrm{Ha}: \mathrm{p}>0$

Ho: $p=0$

H0: there was no positive and significant influence between compensation on teacher performance Ha: there was a positive and significant influence between compensation on teacher performance

Table 3.Results of Partially Linear Regression Analysis of Variable X2 to Y

\begin{tabular}{lcl}
\hline Model & $\mathrm{T}$ & SIG. \\
1 (Constant) & 7.029 & .000 \\
Compensation & 15.145 & .000 \\
\hline
\end{tabular}

Based on Table 3, it was found that $\mathrm{t}$-count $=15.145$ and $\mathrm{t}$-table $=1.98447$, then $\mathrm{t}$-count $>\mathrm{t}$-table which meant that Ho was rejected and Ha was accepted or it was concluded that partially there was a positive and significant influence between compensation on teachers' performance.

In this study, the results of the partial test ( $t$ test) of the compensation variable on performance found that compensation had an influence on teacher performance and it could be said that individual compensation variables had a significant effect on teacher performance with a sig value. was smaller than the probability value and t-count is greater than t-table. This also meant that, if the compensation shown in indicator 1) direct compensation, in the form of (a) monthly salary and (b) bonus; 2) indirect compensation, in the form of (a) financial payments, and (b) increased non-financial payments would be followed by an increase in teacher work productivity and vice versa if compensation decreased, followed by a significant decreased in work productivity. The results of descriptive analysis also found that more than $50 \%$ of respondents stated that they strongly agreed with the research questionnaire statement on the compensation variable, in other words, respondents gave very good responses about the effect of the compensation they received.

One of the factors that influence teacher performance to achieve maximum productivity is compensation, that the factors that influence work productivity can be concluded into two groups, namely: 1) Individual factors, namely age, temperament, individual physical condition, and motivation. ; 2) Factors that exist outside the individual, namely physical conditions such as voice, lighting, rest time, length of work, salary/wages, form, organization, social environment, and family. In this case, the salary / wage is a form of compensation received by teachers in return for productivity. It is not surprising that compensation has a very close relationship with increasing teacher work productivity or vice versa. The more fair the compensation is, the better the work productivity of the teachers will be.

This result is also in line with the results of the author's observations, where the author observed that when teachers of SMP NegeriBabatSupat received compensation from the school, the teachers became more enthusiastic in carrying out tasks, including when they received honoraria in participating in 
personal development such as webinars through zoom meetings, the teachers were very enthusiastic every time they participate in these activities. When making a lesson plan (RPP), the teachers enthusiastically finish it on time, because there was compensation they receive after completing the lesson plan. Thus, compensation had a positive effect on teachers' performance, especially for teachers at SMP Negeri Babat Supat.

Compensation is a reward for the sacrifice of time, energy, and thoughts that the teacher has given in educating their students. In this case, the teacher / teacher / educator is an internal customer who needs to be considered in order to be satisfied in delivering the learning process in the classroom and satisfied with the results achieved by students. Teacher quality will be achieved if the needs expected by the teacher can be met. A very basic teacher need is the need for compensation, where compensation is still not satisfactory, which greatly determines teacher productivity. Teachers received a lot of compensation from the government. Compensation received by teachers, especially teachers with the status of civil servants (PNS), is direct compensation, namely compensation that is limited to direct cash benefits that teachers receive on a monthly basis, for the tasks and functions they have given in educating and implementing learning in schools, which in the form of basic salary. Other compensation besides direct compensation received by teachers is indirect compensation, namely financial and nonfinancial payments of teachers received indirectly to continue their duties and functions in educating and implementing classroom learning which is an important part of any employee compensation, namely in the form of child support and husband / wife, health insurance, pension allowance, certification allowance, teaching allowance, supervisory allowance, teaching excess allowance, and foundation allowance (if the teacher teaches in a private school). All these allowances have been budgeted for in the APBD and APBN. The large amount of compensation received requires teachers to further increase their productivity in schools.

The results of this study is also in line with the results of researches conducted by [14] who found a significant positive influence of compensation on teachers' performance. The better the compensation given to the teacher, the better the teachers' performance would automatically.

3. The Influence of Principal Leadership and Compensation on Teacher Performance of State Junior High Schools in BabatSupat District

Ha: $\rho>0$

Ho: $\rho=0$

H0: there was no positive and significant influence between principal leadership and compensation simultaneously on teacher performance

Ha: there was a positive and significant influence between principal leadership and compensation simultaneously on teacher performance

Table 4.Results of Multiple Linear Regression Analysis Simultaneously(F Test)

\begin{tabular}{lcc}
\hline Model & $\mathrm{F}$ & Sig. \\
Regression & 123.338 & $.000^{\mathrm{b}}$ \\
\hline
\end{tabular}

Based on Table 4, it was known that F-count Fcount $\geq$ Ftable $(123.338>3.09)$ which meant Ha was accepted. It was concluded that there was a significant positive influence between principal leadership and compensation on teachers' performance.

The results of the simultaneous test of the principal's leadership variable and compensation,showed that the probability was much smaller than 0.05 and F-count was greater than F-table, so H04 was rejected and Ha4 was accepted or in other words, there was an effect of principal leadership and compensation simultaneously on teachers' performance. So it can be said that the principal leadership variable and compensation simultaneouslyhad a significant effect on teachers' performance. This also showed that, if the principal's leadership and compensation increasedwould be followed by an increase in teachers' performance and vice versa if the principal leadership and compensation decreased, it would be followed by a significant decrease in the performance of SMP Negeri teachers ofBabatSupat District.

The coefficient of determination test results also found that $71.8 \%$ of the teachers' performance variables could be explained by the principal's leadership and compensation variables. Meanwhile, the remaining $28.2 \%$ was explained by reasons other than the research variables such as competence, working conditions and others.

Principal leadership and compensation are very important factors in efforts to improve teacher performance. In an effort to improve teacher performance, the principal needs to pay attention to the 
factors that affect the performance of his subordinates. There are many factors that can affect teacher performance, both related to the teachers themselves and factors related to the school environment and government policies as a whole. Every school principal as a leader always desires that the teachers he leads are able to improve high performance.

\section{Conclusions}

The following findings are derived based on the discussion of the study results: (1) there was a significant influence between principal leadership on teachers' performance; (2) there was a significant influence between compensation on teachers' performance; (3) there was a significant influence between principal leadership and compensation on teachers performance.

\section{References}

Makawimbang, JH. 2012. KepemimpinanPendidikan yang Bermutu. Bandung: Alfabeta.

Fitria, H., Mukhtar, M., \& Akbar, M. 2017. The Effect of Organizational Structure And Leadership Style on Teacher Performance In Private Secondary School. IJHCM (International Journal of Human Capital Management), 1(02), 101-112.

Kristiawan, M., Yuniarsih, Y., \&Fitria, H. (2019). SupervisiPendidikan. Bandung: Alfabeta

Amirudin, A. 2017.Kepemimpinankepala Madrasah dalammeningkatkankedisiplinan guru. Al-idarah: jurnalkependidikanislam, 7(2), 23-37.

Wagiran. 2013. Model Penguatan Soft Skills dalamMewujudkanCalon Guru KejuruanProfesionalBerkarakter. JurnalKependidikan. Yogyakarta: LPPM UNY.

Makawimbang, JH. 2012. KepemimpinanPendidikan yang Bermutu. Bandung: Alfabeta.

Moeheriono, 2010.PengukuranKinerjaBerbasisKompetensi, Cetakankedua, Jakarta: Ghalia Indonesia.

Rivai, V., \&Sagala, E. J. 2009.ManajemensumberDayaManusiauntuk Perusahaan, edisikedua. Penerbit: RajawaliPers, Jakarta.

Arikunto, S. 2010. ProsedurPenelitianSuatuPendekatanPraktik. Jakarta: RinekaCipta.

Karwati, E., \&Priansa, D. J. 2013. Principal Performance and Professionalism. Bandung: Alfabeta.

Andriani, S., Kesumawati, N., \&Kristiawan, M. 2018.The Influence of the Transformational Leadership and Work Motivation on Teachers Performance. International Journal of Scientific \& Technology Research, 7(7), 19-29.

Nurhayati, S. 2006. PendekatanPerilakuKepemimpinanDalamUpayaMeningkatkanKemampuan Usaha PadaPengusahaIndustri Kecil Sepatu Dan Sandal Di WedoroSidoarjo (Doctoral Dissertation, UniversitasAirlangga).

Lukman, L., Lian, B., \& Sari, A. P. 2020.The Influence of Principal's Leadership and Work Motivation toward Teacher's Performance. International Journal of Progressive Sciences and Technologies, 22(1), 376379.

Handayani, T. 2015. PengaruhKompensasiterhadapKinerja Guru. JurnalUtilitas, 1(1), 24-34. 